\title{
Characterization of 3D-Printing Filament with Extruder Melting Temperature Variation for Bone Implant From Kupang Shell
}

\author{
Ananda Maulidha Kusumastuti ${ }^{1 *}$, Adik Roni Setiawan ${ }^{1}$, Asalina Putri Agung Shaliha ${ }^{1}$, Deden \\ Eko Wiyono ${ }^{1}$, Achmad Ferdiansyah Pradana Putra ${ }^{1}$ \\ ${ }^{1}$ Institut Teknologi Sepuluh Nopember (ITS), \\ Industrial Chemical Engineering, Surabaya, Indonesia \\ Email: ${ }^{* * a n a n d a m a u l i d h a @ g m a i l . c o m ~}$
}

Received: 2021-10-22 Received in revised from 2021-10-29 Accepted: 2022-01-05

\begin{abstract}
Abstrak
Angka kerusakan tulang di Indonesia terus meningkat. Implan tulang merupakan salah satu metode penanganan medis yang dilakukan pada kerusakan tulang. Material organic dan non-organik dapat digunakan sebagai bahan implant tulang. Material non-organik bersifat lebih kuat, namun tidak biokompatibel, sedangkan material organic bersifat biokompatibel, tetapi bersifat rapuh. Penambahan polimer polikaprolakton (PCL) dapat meningkatkan kekuatan mekanis dari filamen implant tulang $3 D$ printing. Suhu melting extruder merupakan salah satu faktor yang mempengaruhi kualitas filament PCL-HAp untuk implan tulang. Studi terkait variasi suhu pada material PCL-HAp belum banyak diteliti. Oleh karena itu perlu dilakukan karakterisasi filamen $3 D$ printing dengan variasi suhu melting extruder sebagai implan tulang dari cangkang kupang dengan variabel suhu $65^{\circ} \mathrm{C}, 75^{\circ} \mathrm{C}$, dan $85^{\circ} \mathrm{C}$. Dari penelitian ini didapatkan titik optimum pada suhu melting extruder $75^{\circ} \mathrm{C}$ dengan hasil diameter 1,810 dan mechanical strength yang menunjukkan adanya peningkatan kuat tarik dan modulus young dari komposit PCL-HAp pada semua variabel dibandingkan dengan PCL murni. Uji SEM menunjukan permukasaan kasar pada filamen yang dapat meningkatkan proliferasi dan adhesi sel-sel yang baik untuk pertumbuhan jaringan tulang.
\end{abstract}

Kata Kunci: Hidroksiapatit, Implan Tulang, Suhu Melting Extruder

\begin{abstract}
The number of bone damage in Indonesia continues to increase. Bone implant is one of the medical treatment methods performed on bone damage. Organic and non-organic materials can be used as bone implants. Non-organic materials are stronger, but not biocompatible, while organic materials are biocompatible, but brittle. The addition of polycaprolactone polymer (PCL) can increase the mechanical strength of 3D printing bone implant filaments. Extruder melting temperature is one of the factors that affect the quality of PCL-HAp filaments for bone implants. Studies related to temperature variations in PCL-HAp materials have not been widely studied. Therefore, it is necessary to characterize 3D printing filaments with variations in the melting temperature of the extruder as bone implants from mussel shells with temperature variables of $65^{\circ} \mathrm{C}, 75^{\circ} \mathrm{C}$, and $85^{\circ} \mathrm{C}$. From this study, the optimum point was found at the melting extruder temperature of $75^{\circ} \mathrm{C}$ with the results of a diameter of 1.810 and mechanical strength which showed an increase in tensile strength and Young's modulus of PCL-HAp composite in all variables compared to pure PCL. The SEM test showed a rough surface on the filaments that could increase the proliferation and adhesion of good cells for the growth of bone tissue.
\end{abstract}

Keywords: Hydroxyapatite, Bone Implant, Extruder Melting Temperature 


\section{Introduction}

Cases of bone injury in Indonesia continue to increase. According to the Central Statistics Agency, the number of traffic accidents has almost doubled in recent years. In the period 2007-2015, there was a $99.72 \%$ increase in the incidence of accidents. This does not include bone damage due to degenerative diseases, such as osteoarthritis and osteoporosis. The high number of cases of bone damage is driving the demand for prostheses, which are artificial components such as replaced bone or bone implants. But in fact $94 \%$ of medical device products in Indonesia are still imported from abroad, one of which is bone implants. According to BPS in 2016, data on the need for bone implants was around Rp. 20 trillion, increasing to Rp. 23 trillion in 2017 and is predicted to reach Rp. 27 trillion in 2018 [1].

Seeing this great potential, the researchers conducted research on bone implants. One of them according to literature, the manufacture of bone implants, the selection of materials can be adjusted to the mechanical properties and uses. For example, stainless steel is recommended for weight-bearing bones with less friction, such as knees. While ceramics are recommended for joints that rub a lot like the hip joint. From this description, it can be concluded that stainless steel is a good material for bone because it has strong mechanical properties but is not suitable for tissue. Ceramic is also a good material for bones because it is a good fit for tissue but this material is brittle so it can't be impacted. Therefore, appropriate materials are needed in the manufacture of bone implants [2].

Most of the bone implants are still made using the cast technique. according to some research, the process of casting magnesium-based bone implants is not easy because the cast products tend to produce inhomogeneous macro and micro porosity. In addition, the bone implant casting technique requires a long time with a high level of complexity because each patient has different bone characteristics. Therefore, a new technique was developed using 3D printing technology. This technology is one way to make a wide variety of products including bone implants with a faster time and higher level of precision [3].

There are several factors that must be considered in the application of 3D printing technology in order to get maximum results, including filament diameter, filament homogeneity, extruder nozzle mechanism, and extruder melting temperature. Filaments quality are characterized by high durability and constant diameter. If the diameter of the resulting filament is not the same, then the level of homogeneity of the filament is low. This will have an impact on the quality of the resulting 3D printing implant[4]. One of the factors that greatly affects the 3D printing filament is controlling the extruder temperature according to the melting point of the polymer material [5].

Further research on the extruder melting temperature was with the production of semicrystalline Polylacticacid (PLA) filaments. which then extruded with a nozzle size of $2.85 \mathrm{~mm}$ and temperatures of $175^{\circ} \mathrm{C}, 180^{\circ} \mathrm{C}, 190^{\circ} \mathrm{C}$, and $195^{\circ} \mathrm{C}$ [6]. The results of the research are: The optimum temperature was obtained at 175 and $180^{\circ} \mathrm{C}$ with a filament diameter of 2.3-2.6 mm.Similar research was conducted by using PLA material with a nozzle temperature of $190 \mathrm{oC}, 205 \mathrm{oC}, 220 \mathrm{oC}$. In this research, the density results that are closest to the density of the material are at a nozzle temperature of $190^{\circ} \mathrm{C}$ with a filament diameter of $1.75 \mathrm{~mm}$. Thus, the extruder melting temperature of each polymer has its optimum point. This is because the temperature in the melting chamber must be kept as close as possible to the melting point of the polymer. If the extruder melting temperature is too high, it can cause residue to form in the melting chamber, causing contamination of the remaining material [7].

Most researchers use 3D printing filaments for bone implants made from PLA composites and combined with Hydroxyapatite (HAp) compounds. HAp is one of the bioactive materials that can regenerate damaged bone tissue in humans because HAp has excellent biocompatibility, osteoconductivity, and chemical and biological affinity with bone tissue [8]. However, PLA-HAp filament composites have several drawbacks, namely they are hydrophobic and can cause inflammation in the surrounding body tissues [9].

Other polymers that are more appropriate for use in biomedical technology are polycaprolactone (PCL). PCL has corrosion resistance properties, can be degraded slowly, and is biocompatible so it does not have the potential to cause inflammation because it is classified as medical grade. In addition, PCL also has excellent mechanical properties and is more affordable [10]. PCL has a low glass transition temperature $(\mathrm{Tg})-60^{\circ} \mathrm{C}$, a tensile strength of $16 \mathrm{MPa}$, a tensile modulus of $400 \mathrm{MPa}$, a flexural modulus 
of $500 \mathrm{MPa}$, an elongation of $7 \%$ and an elongation of $7 \%$. until it drops out at $80 \%$ [11]. PCL has been widely used for biomedical applications such as catheters, surgical threads, and drug delivery.

Research related to the melting temperature of extruders with PCL-HAp polymer which is safer as a biomedical device has never been done. In fact, the extruder melting temperature greatly affects the quality of the resulting 3D printing filament. Therefore, further research is needed to determine the optimum extruder melting temperature in the PCL-HAp mixture as a material for printing bone implants using $3 \mathrm{D}$ printing. The extruder melting temperature variables in the manufacture of PCL-HAp filaments were chosen at $65^{\circ} \mathrm{C}, 75^{\circ} \mathrm{C}$, and $85^{\circ} \mathrm{C}$ because they are not far from the melting point, which is around $60^{\circ} \mathrm{C}$. The results obtained were analyzed using SEM and Mechanical Strength to determine the structure and mechanical strength [13].

\section{Method}

\section{Tools and materials}

The tools used in this research are Single Screw Extruder Wellzoom, furnace, glass beaker, erlenmeyer, volume pipette, porcelain dish, mortar, pestle, hot plate stirrer, magnetic stirrer, watch glass, thermometer, funnel, filter paper, crucible, and crucible pliers. The materials used were mussel shells, 99.8\% glacial acetic acid, $\mathrm{KH}_{2} \mathrm{PO}_{4}$ analytical grade MERCK, and PCL.

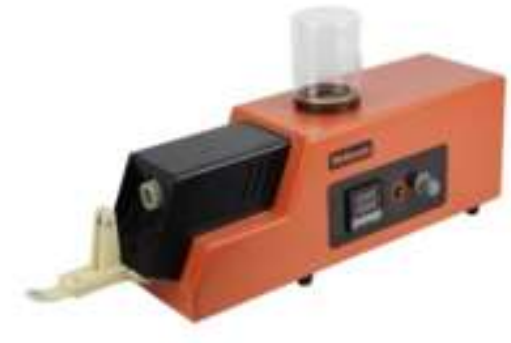

\section{Specification:}

- Extrusion rate: $10 "$ - 26" / min

- Diameter: $1.75 \mathrm{~mm}$ and $3.00 \mathrm{~mm}$

- Extrusion accuracy $0.05 \mathrm{~mm}$ (in $1.75 \mathrm{~mm}$ ); $0.1 \mathrm{~mm}$ (in 3mm)

- Adapt material: PLA, ABS, PVA, wood-plastic, etc.

- Working temperature $\sim 300^{\circ} \mathrm{C}$

Figure 1. Filament Extruder

\section{Pre-treatment}

The raw material pre-treatment starts with washing the mussel shells from the impurities. Then allowed to stand at room temperature for 24 hours. The dried mussel shells are then pounded using a mortar and pestle which aims to maximize the calcination process in the furnace.

\section{Kupang Shell Calcination Stage}

At this stage, the pounded mussel shells are put into the crucible. Then enter the crucible containing mussel shells into the furnace with operating conditions $\mathrm{T}=1000^{\circ} \mathrm{C}$ for 5 hours.

\section{Hydroxyapatite (HAp) Synthesis Stage}

This stage begins with making a solution of $\mathrm{KH}_{2} \mathrm{PO}_{4}$ by dissolving 114 grams of $\mathrm{KH}_{2} \mathrm{PO} 4$ into distilled water up to $500 \mathrm{~mL}$. After that, drip $20 \mathrm{~mL}$ of $\mathrm{KH}_{2} \mathrm{PO}_{4}$ solution, plus $5 \mathrm{~g}$ of $\mathrm{CaO}$. Then put into $250 \mathrm{~mL}$ of distilled water then the solution was stirred until homogeneous with a magnetic stirrer and kept the temperature at $37^{\circ} \mathrm{C}, 30$ minutes at $30 \mathrm{rpm}$. Then precipitate the solution for 24 hours. Then the precipitate is filtered and washed. After that, it was heated in an oven at $110^{\circ} \mathrm{C}$ for 3 hours. The HAp was obtained and then sintered the dry precipitate at a temperature of $800^{\circ} \mathrm{C}$ for 4 hours.

\section{PCL-Hydroxyapatite (HAp) Composite Synthesis Stage}

Dissolve $20 \%$ of the solution (w/v) in the ratio (w.PCL/v. $\mathrm{CH}_{3} \mathrm{COOH}$ ) which is $10 \mathrm{~g}$ of PCL in $50 \mathrm{~mL}$ of $100 \% \mathrm{CH}_{3} \mathrm{COOH}$. Then, add the HAp powder with the ratio of PCL: HAp (9: 1) and stir the solution using a magnetic stirrer for 2 hours to form a homogeneous paste solution. The solution is then placed into a mold and remove the solvent by leaving it in a fume hood for $1 \times 24$ hours and in the oven. After solidification, cut the resulting solid mixture of HAP-PCL which has been removed by solvent and followed by extrusion using an extruder according to the specified temperature variables, namely $65^{\circ} \mathrm{C}, 75^{\circ} \mathrm{C}$, and $85^{\circ} \mathrm{C}$. 


\section{Analysis Stage}

XRF Analysis (X-Ray Fluorescence)

XRF (X-Ray Fluoresence) analysis is a method to be able to quickly analyze the elemental composition in a sample. The principle used is the determination of the elemental composition based on the interaction of X-rays with matter.

\section{FTIR Analysis}

Fourier Transform Infra Red (FTIR) analysis is a technique for obtaining infrared spectra of the absorption or emission of solid, liquid, or gaseous substances for the purpose of identifying compounds, detecting functional groups, and analyzing the mixture and sample being analyzed.

XRD analysis

X-ray Diffraction (XRD) analysis is a quantitative and qualitative analysis based on X-ray diffraction of a material in the form of powder or solid (block) from inorganic samples in the form of polycrystalline and amorphous.

\section{SEM Analysis}

Screening Electron Microscopy (SEM) analysis is an observation technique with an electron microscope that is used to investigate the surface of a solid object directly with a magnification of 10 $3000000 x$, depth of field $4-0.4 \mathrm{~mm}$ and a resolution of $1-10 \mathrm{~nm}$.

\section{Mechanical Strength Analysis}

This mechanical strength analysis aims to determine the mechanical strength of an object with test parameters:

- Yield Strains i.e. the starting point where strain begins to occur on the stress-strain curve where there is an increase in strain without any increase in stress.

- Tensile strengthis the ability of a material to withstand loads without damage. The tensile strength of a material is determined by dividing the maximum force by the initial cross-sectional area before deformation, equation 1 :

$$
\delta=\frac{F_{m a k s}}{A_{o}}
$$

where:

$\begin{array}{lll}-\quad \alpha & =\text { tensile strength of the material } & (\mathrm{kgf} / \mathrm{mm} 2) \\ -\quad \mathrm{fmax} & =\text { Maximum stress } & (\mathrm{kgf}) \\ -\quad A_{\mathrm{o}} & =\text { Original cross-sectional area } & (\mathrm{mm} 2)\end{array}$

- Break Strains is the percentage of the value obtained in the division between the addition of the length to the break elongation and the initial gauge length, equation 2 :

$$
\varepsilon=\frac{\Delta l}{l_{o}} \times 100 \text { 응 }
$$

\begin{tabular}{|c|c|}
\hline$\alpha$ & $=$ tensile strength of the material \\
\hline$\varepsilon$ & $=$ Break Strains \\
\hline$\Delta l$ & $=$ Length at maximum moment \\
\hline$l 0$ & $=$ Original length \\
\hline
\end{tabular}

where:

- Young's modulus defined as the value of the gradient or slope of the straight line. So from the curve Young's modulus is determined by the equation 3:

$$
Y=\frac{\sigma_{2}-\sigma_{1}}{\varepsilon_{2}-\varepsilon_{1}}=\frac{\Delta \sigma}{\Delta \varepsilon}
$$

where:

$$
\begin{aligned}
& \text { - } \mathrm{Y}=\text { modulus of elasticity }\left(\mathrm{N} / \mathrm{m}^{2}\right) \\
& \text { - } 2=\text { stress at point } 2 \text { (end) } \\
& \text { - } 1 \text { = stress at point } 1 \text { (start) }
\end{aligned}
$$


$\begin{array}{lll}- & 2 & =\text { strain at point } 2 \text { (end) } \\ - & 1 & =\text { strain at point } 1 \text { (start) } \\ - & \Delta \sigma & =\text { stress difference between } 2 \text { dots } \\ - & \Delta \varepsilon & =\text { strain difference between } 2 \text { dots }\end{array}$

\section{Results and Discussion}

Analysis of the Effect of Calcination of Kupang Shells on Calcium Oxide (CaO) Content

Calcination is a chemical reaction process that functions to change the phase of Calcium Carbonate $\left(\mathrm{CaCO}_{3}\right)$ into Calcium Oxide $(\mathrm{CaO})$. The reactions that occur in the calcination process are as follows:

$$
\mathrm{CaCO}_{3}(\mathrm{~s}) \rightarrow \mathrm{CaO}(\mathrm{s})+\mathrm{CO}_{2}(\mathrm{~g}) \uparrow
$$

In this calcination stage, the raw material used is mussel shells (Corbula faba) which have been separated from the impurity material. The main substance that will be taken from the raw material of this mussel shell is $\mathrm{CaO}$ which will be reacted with Potassium Hydrogen Phospate $\left(\mathrm{KH}_{2} \mathrm{PO}_{4}\right)$ to become Hydroxyapatite (HAp). Therefore, it is very important to know the level of $\mathrm{CaO}$ contained in mussel shells by testing the content of the calcination process of mussel shells. High levels of $\mathrm{CaO}$ can be represented by the presence of Calcium $(\mathrm{Ca})$ contained in a compound. To determine the $\mathrm{Ca}$ content of mussel shells from the calcination process, the XRF. test method was used (X-Ray Fluorescence).The description of the XRF test results (X-Ray Fluorescence)are as follows :

Table 1. Comparison of Test Results for Sample Content from the Calcination Process of Beef Bone* and Kupang Shells

\begin{tabular}{cccc}
\hline \multirow{2}{*}{ Test Type } & Component & \%Beef Bone Level* & \% Kupang Shell Content \\
& & & \\
\hline \multirow{3}{*}{ Element } & $\mathrm{Pa}$ & 8.07 & 0 \\
& $\mathrm{Fe}$ & 89.88 & 99.16 \\
& $\mathrm{Cu}$ & 0.40 & 0.12 \\
& $\mathrm{Zn}$ & 0.077 & 0.055 \\
$\mathrm{M} \mathrm{N}$ & 0.51 & 0 \\
& $\mathrm{Sr}$ & 0 & 0.039 \\
$\mathrm{Re}$ & 0.93 & 0.637 \\
& $\mathrm{Yb}$ & 0.1 & 0 \\
& & 0.49 & 0 \\
\hline
\end{tabular}

Based on Table 1. the Ca content in mussel shells is $99.16 \%$ while that in beef bones is $89.88 \%$. The high content of $\mathrm{Ca}$ is proportional to the presence of $\mathrm{CaO}$ compounds contained in a material. Therefore, the $\mathrm{CaO}$ compound content of the mussel shell sample has a very large potential to be used as a hydroxyapatite synthesis material in bone implants.

\section{Analysis of Hydroxyapatite Content of Kupang Shells}

After the formation of $\mathrm{CaO}$ from the calcination of mussel shells, the next step is the synthesis of HAp using the precipitation method. Where the precipitation stage aims to obtain the content of Phosphate compounds $\left(\mathrm{PO}_{4}{ }^{3-}\right)$ which is used for the HAp synthesis stage. As for one of the compounds that can produce Phosphate is KH2PO4. The result of mixing the two compounds is HAp. The reaction equation for the formation of HAp is as follows:

$$
\begin{aligned}
\mathrm{CaO}(\mathrm{s})+\mathrm{H}_{2} \mathrm{O}(\mathrm{l}) & \rightarrow \mathrm{Ca}(\mathrm{OH})_{2}(\mathrm{aq}) \\
6 \mathrm{KH}_{2} \mathrm{PO}_{4}(\mathrm{aq})+\mathrm{H}_{2} \mathrm{O}(\mathrm{l})+10 \mathrm{Ca}(\mathrm{OH})_{2}(\mathrm{aq}) & \rightarrow \mathrm{Ca}_{10}\left(\mathrm{PO}_{4}\right)_{6}(\mathrm{OH})_{2}(\mathrm{~s}) \downarrow+6 \mathrm{H}_{2} \mathrm{O}(\mathrm{l})+3 \mathrm{~K}_{2} \mathrm{O}(\mathrm{s})
\end{aligned}
$$




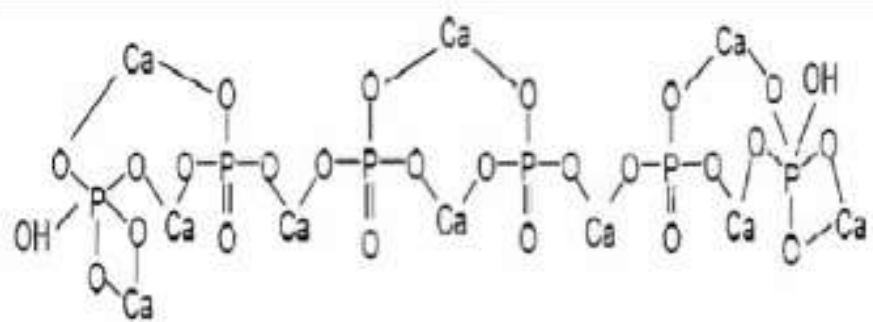

Figure 2. HAp Structural Formula

At this precipitation stage, the raw material of $\mathrm{CaO}$ resulting from the calcination of mussel shells is given aquades which aims to convert $\mathrm{CaO}$ into Calcium Hydroxide $\mathrm{Ca}(\mathrm{OH})_{2}$ which will be reacted with $\mathrm{KH}_{2} \mathrm{PO}_{4}$ to form Hydroxyapatite compound $\left[\mathrm{Ca}_{10}\left(\mathrm{PO}_{4}\right)_{6}(\mathrm{OH})_{2}\right]$. As for knowing the qualitative results, the content of HAp can be known through the FTIR (Fourier Transform Infra Red) test with the wavelength range of the functional groups that make up HAp are as follows:

Table 2. The HAp Functional Group Wavelength Range of the Kupang Shell

\begin{tabular}{ccc}
$\begin{array}{c}\text { Functional } \\
\text { groups }\end{array}$ & $\begin{array}{l}\text { Kupang mussels } \\
\left(\mathbf{c m}^{-1}\right)\end{array}$ & $\begin{array}{l}\text { Wavelength Range } \\
\left(\mathbf{c m}^{-1}\right)^{*}\end{array}$ \\
\hline Phosphate & 1023.85 & $950-1100$ \\
hydroxyl & 3641.01 & $3600-3700$ \\
carbonate & 1413.37 & $1400-1550$ \\
\hline
\end{tabular}

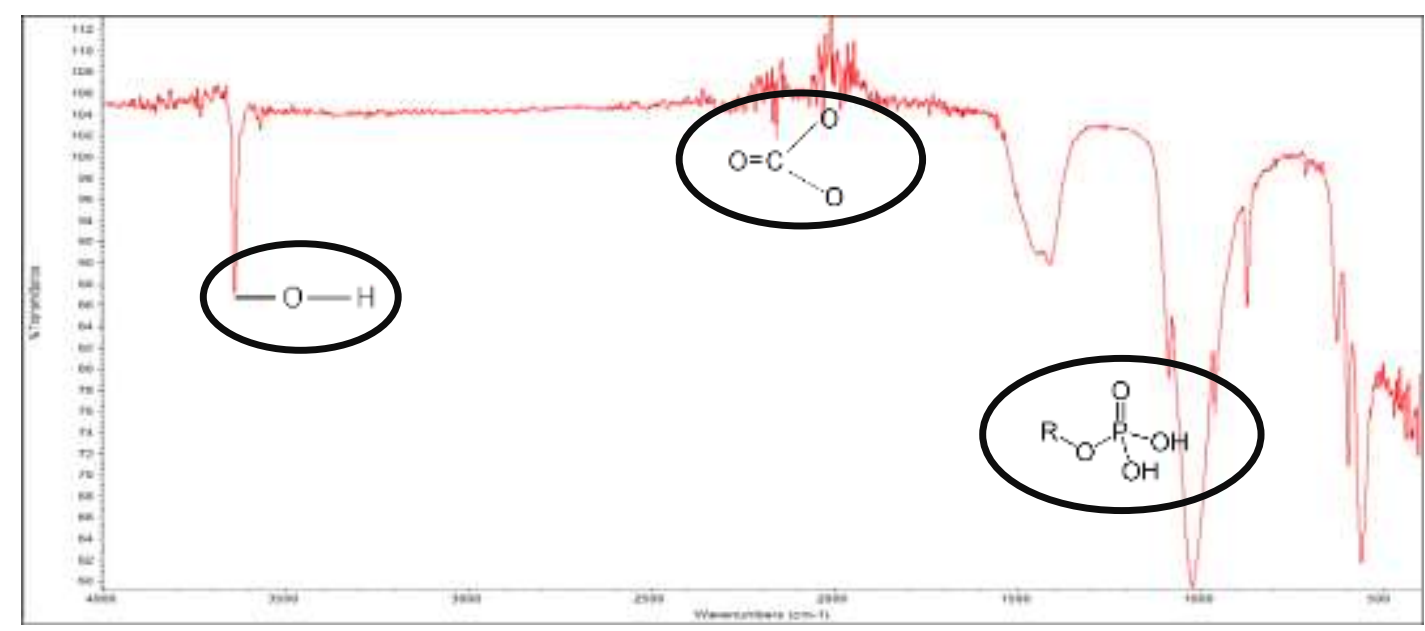

Figure 3. FTIR HAp Analysis Results from Kupang Shells

Based on the FTIR results in Figure 3. it is found that the phosphate group bond $(\mathrm{P}=\mathrm{O})$ is the highest intensity at a wavelength of $1023.85 \mathrm{~cm}^{-1}$. This peak indicates the presence of a phosphate group bond which is characterized by stretching and bending vibrations. The hydroxyl group $(-\mathrm{O}-\mathrm{H})$ was detected at a wave number of $3641.01 \mathrm{~cm}^{-1}$ which indicated the presence of hydrogen bonds with the vibration of the $\mathrm{H}-\mathrm{O}-\mathrm{H}$ functional group. The carbonate group bond $(\mathrm{C}=\mathrm{O})$ is shown at a wavelength of $1413.37 \mathrm{~cm}^{-1}$. the results of the FTIR analysis of HAp from mussel shells in Table 2. have similar intensity peaks so that it can be concluded that HAp has formed which is evidenced by the presence of phosphate group bonds $\left(\mathrm{PO}_{4}{ }^{3-}\right)$ and $\mathrm{OH}^{-}$group on $\mathrm{HAp}$ of mussel shell with $\mathrm{Ca} / \mathrm{P}$ 1.67.

After knowing the presence or absence of HAp content qualitatively by using the FTIR test, then proceed with quantitative analysis which serves to determine the levels of HAp contained in the 
compound from the results of the HAp synthesis process. The quantitative analysis used is the XRD test method (X-ray Diffraction) with the following results:

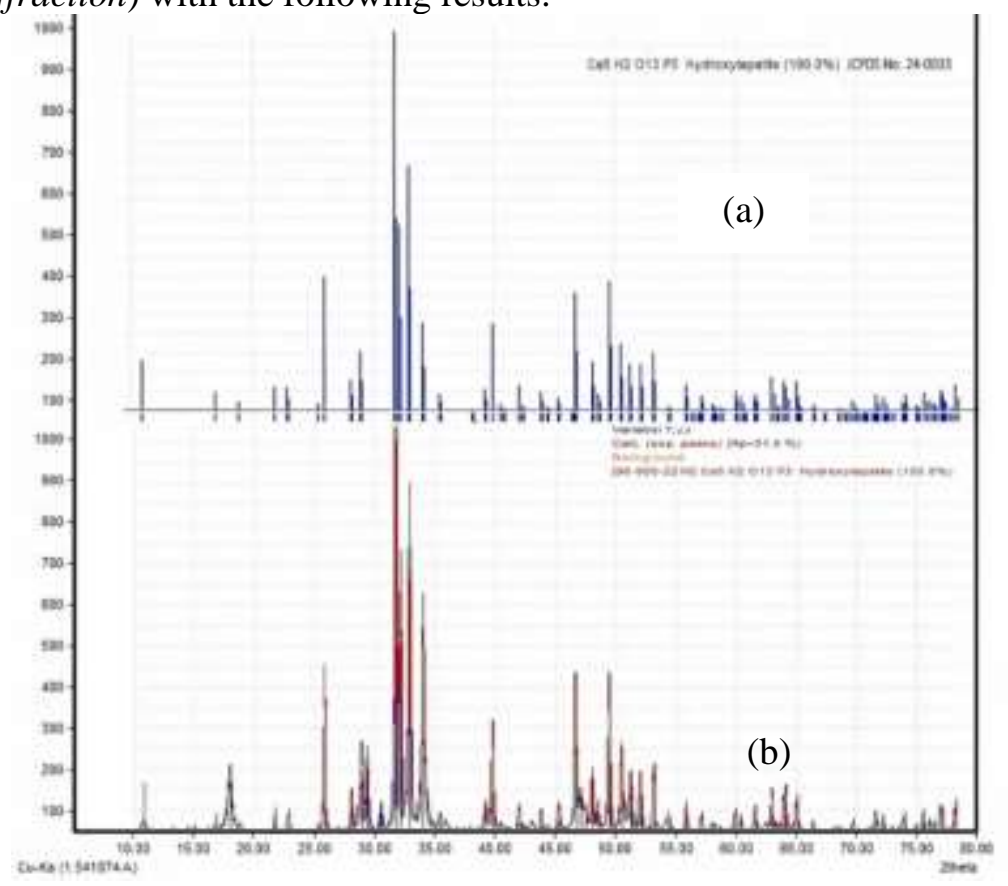

Figure 4. XRD Test Results of the Hydroxyapatite Synthesis Process from (a) pure HAp JCPDS No. 09-432* and (b) Shell of Kupang

*Data taken from Literature [15]

Based on Figure 4. obtained HAp crystals from mussel shells indicated by the peaks of the highest intensity of HAp at peak 31,$785 ; 31,866 ; 32,921 ; 33,005,34,071 ; 34,158$. The intensity obtained from the HAp of mussel shells has a similar peak with the reference data of XRD JCPDS No. 09-432. This indicates that the research results obtained are HAp compounds.

Table 3. XRD Test Results from Hydroxyapatite (HAp) Synthesis Process

\begin{tabular}{cccc}
\hline \multicolumn{4}{c}{ Ca/P 1.67 } \\
\hline Entry & Sum formula & Name & Quant.(\%) \\
$96-900-2216$ & $\mathrm{Ca5} \mathrm{H2} \mathrm{O13} \mathrm{P3}$ & Hydroxylapatite & 85.2 \\
$96-702-0139$ & $\mathrm{Ca} \mathrm{H} 2 \mathrm{O} 2$ & $\mathrm{Ca}(\mathrm{OH})_{2}$ & 10.2 \\
$96-901-1979$ & $\mathrm{~K}$ & Potassium & 2.0 \\
\hline
\end{tabular}

The XRD analysis data obtained were then processed using the Match! software. Version 3.0 compares the diffraction pattern of the sample to a database containing reference patterns to identify the existing phase as a qualitative analysis, while for quantitative analysis it is carried out with Rietveld refinements. To obtain semi-quantitative data the degree of crystallinity of the sample. Based on Table 3. the degree of crystallinity of the hydroxyapatite crystals formed is $85.2 \%$. HAp with a degree of crystallinity above $70 \%$ belonged to a high degree of crystallinity. The higher the degree of crystallinity of HAp in a sample, the closer to the perfect crystal form. This indicates that the main crystal in the sample is Hydroxyapatite. 


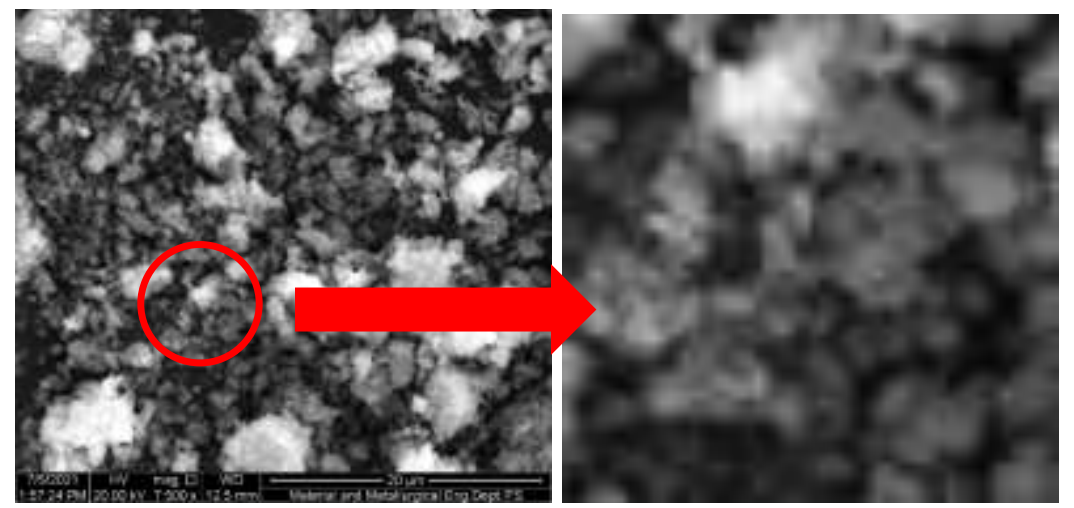

Figure 5. Results of HAp SEM Analysis from Kupang Shells

Based on the XRD analysis that has been mentioned above, it is known that there is HAp content. To determine the HAp morphology structure and particle distribution using SEM analysis. It can be seen from Figure 5 that the results of the SEM HAp of mussel shells with this process have a hexagonal shape. Pure HAp obtained stoichiometrically with a $\mathrm{Ca} / \mathrm{P}$ ratio of 1.67 showed monoclinic particle shape which was thermodynamically more stable when heated, while hexagonal was better for tissue growth.

The SEM data were reprocessed using the ImageJ application to obtain particle size distribution data from each sample using the sampling method. The data obtained were grouped using the OriginPro application to obtain a graph of the particle size distribution of each sample to obtain a graph as shown in Figure 6.

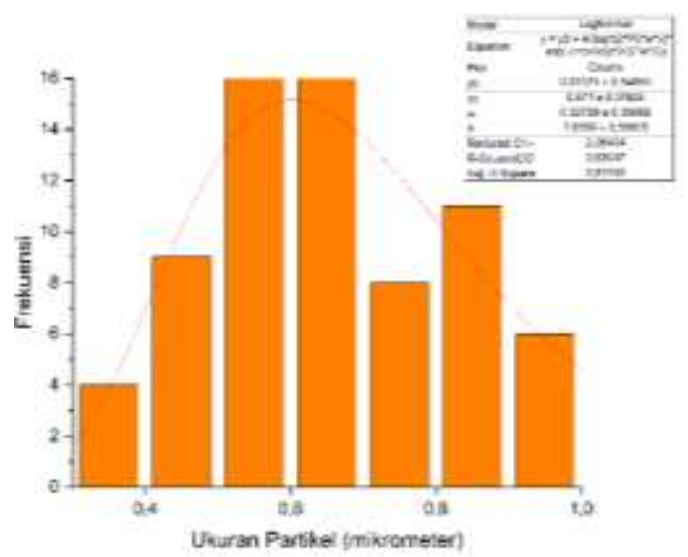

Figure 6. Distribution of particle sizes on HAp from Kupang Shells

In Figure 6. the average particle size of HAp shells of mussel shells is $0.671 \mu \mathrm{m}$, while based on the average particle size of beef bone HAp is $0.688 \mu \mathrm{m}$. The smaller particle size can increase the mechanical ability of the HAp composite due to the increase in the specific surface area and the distribution area of the two composite materials when mixing. Thus, HAp from mussel shells can be mixed with a polymer to produce composites with stronger mechanical properties.

\section{Filament Analysis of the HAp-PCL . Composite Synthesis}

After the formation of HAp, the next step is the synthesis of the HAp composite with a polymer, namely polycaprolactone. Polycaprolactone (PCL) is a biodegradable polymer that can be used in the manufacture of medical standard equipment and materials. The mixture of the two composites will be processed into 3D printing filaments for bone implants. The composition ratio of the mass ratio of the HAp-PCL mixture is 9: 1. From the two mixtures, $50 \mathrm{~mL}$ of $100 \%$ acetic acid $\left(\mathrm{CH}_{3} \mathrm{COOH}\right)$ is given and stirred until it becomes a homogeneous solution (a paste solution is formed). The purpose of the addition of acetic acid is as a solvent of the two components but not corrosive. After that, 
The result formed is what will become a 3D printing filament by extruding it using an extruder for bone implants. The results of the filament extrusion process from the HAp-PCL synthesis are as follows:

Table 4. Filament Results from the Extrusion Process

\begin{tabular}{ccc}
\hline Temperature & Particle size & Filament Yield \\
\hline $650 \mathrm{C}$ & $1,210 \mathrm{~mm}$ & \\
\hline $750 \mathrm{C}$ & $1,810 \mathrm{~mm}$ & \\
\hline $850 \mathrm{C}$ & $1.21 \mathrm{~mm}$ & \\
\hline
\end{tabular}

Based on Table 4. the optimum particle size value of the filament results from the extrusion process occurs at the extruder temperature variables of $70^{\circ} \mathrm{C}$ and $75^{\circ} \mathrm{C}$, where the value of the particle size of the filament is obtained which is close to the size of the particle size of the filament in the market, namely at $1.75 \mathrm{~mm}$. The decrease in particle size values at higher temperatures is caused by the presence of burning material and causing residues in the liquefier chamber, as well as contaminating other materials [7]. While the low temperature causes a decrease in the roundness of the filament. The increase in roundness is directly proportional to the extrusion speed. In addition, we observed that the low extrusion temperature drastically reduces the range of potential values for the extrusion speed. This can be due mainly to an increase in viscosity with a decrease in nozzle temperature, which is also evidenced by the equation of viscosity as a function of temperature.

To determine the quality of the filament results, it can be seen through the SEM (Screening Electron Microscopy) test) filament on a 3 point variable that can represent the results of the practicum. The results of the SEM test are as follows:

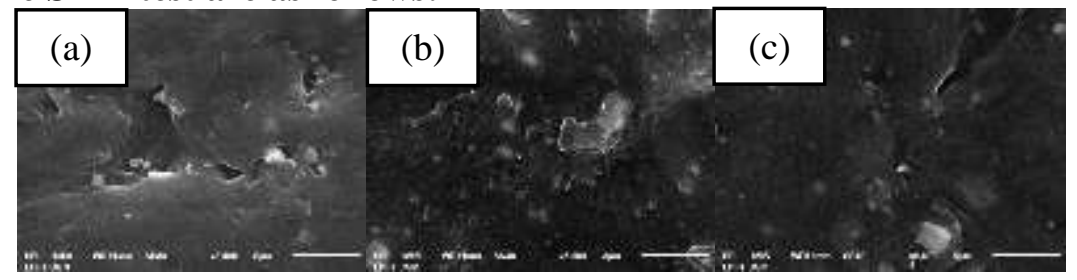

Figure 8 Results of SEM Analysis of PCL-HAp Composite Filaments with temperature variations (a) $65^{\circ} \mathrm{C}$, (b) $75^{\circ} \mathrm{C}$, and (c) $85^{\circ} \mathrm{C}$

Based on Figure 8, the results of the SEM analysis of PCL-HAp composite filaments at temperature variations of $65^{\circ} \mathrm{C}, 75^{\circ} \mathrm{C}$, and $85^{\circ} \mathrm{C}$ showed the presence of a rough surface on the 3D printing filament. The rough surface of a filament can increase proliferation (cell phase when undergoing cell cycle repetition without inhibition) and cell adhesion so that it is good for tissue growth in bone.

Table 5. Mechanical Strength Test Results on Extruder Melting Temperature Variables

\begin{tabular}{ccccc}
\hline \multirow{2}{*}{ Sample } & \multicolumn{4}{c}{ Mechanical Strength } \\
\cline { 2 - 5 } & Stress (MPa) & Strains (\%) & Break (Mpa) & $\begin{array}{c}\text { Young's modulus } \\
\text { (Mpa) }\end{array}$ \\
\hline Pure $\mathrm{PCl}$ & 5.03 & 4.6 & 5.03 & 293.71 \\
Variable $65^{\circ} \mathrm{C}$ & 4.83 & 1.96 & 8.15 & 478.4 \\
Variable $75^{\circ} \mathrm{C}$ & 3.44 & 2.24 & 8.23 & 418.09 \\
Variable $85^{\circ} \mathrm{C}$ & 3.76 & 3.07 & 8.63 & 429.56 \\
\hline
\end{tabular}

Table 5 shows that there is an increase in tensile strength and Young's modulus of the PCLHAp composite in all variables from pure PCL. This is due to the presence of dThe uniform distribution of HAp particles in the PCL polymer may allow for improved mechanical properties, including tensile 
strength and yield compressive strength. More specifically, the HAp phase can have a much higher rigidity than the more flexible PCL polymer, thus more effectively withstanding the applied load, as is often the case with organic and inorganic composites.

\section{Conclussion}

The 3D printing PCl-HAp filament composite was successfully carried out and the optimum point was obtained at a melting extruder temperature of $75^{\circ} \mathrm{C}$ with the diameter of the filament obtained is $1.810 \mathrm{~mm}$. This is in accordance with the standard filament size on the nozzle commonly used in 3D printing, which is more than $1.7 \mathrm{~mm}$. The results of the SEM analysis of the PCL-HAp composite filament at a temperature variation of $75^{\circ} \mathrm{C}$ showed the presence of a rough surface on the $3 \mathrm{D}$ printing filament, which could increase the proliferation and adhesion of cells so that it is good for tissue growth in bone. The results of the mechanical strength showed that there was an increase in the tensile strength and Young's modulus of the PCL-HAp composite in all variables from pure PCL.

\section{Acknowledgments (optional)}

This work was financially supported by Ministry of Education and Culture 2021 Student Creativity Program activities based on Decree Number: 1949/E2/KM.05.01/2021 with serial number 1762, and the Applied Chemistry Laboratory, Department of Industrial Chemical Engineering - ITS.

\section{Referensi}

[1] A. Budianto, "Pirolisiss Botol Plastik Bekas Minuman Air Mnieral Jenis Pet Menjadi Fuel," Semin. Nas. Sains dan Teknol. Terap. V, pp. 201-206, 2017.

[2] A. Budianto, D. H. Prajitno, and K. Budhikarjono, "Biofuel Production From Candlenut Oil Using Catalytic Cracking Process With Zn / Hzsm-5 Catalyst," ARPN J. Eng. Appl. Sci., vol. 9, no. 11, pp. 2121-2124, 2014.

[3] A. Budianto, W. S. Pambudi, S. Sumari, and A. Yulianto, "PID control design for biofuel furnace using arduino," Telkomnika (Telecommunication Comput. Electron. Control., vol. 16, no. 6, 2018.

[4] M. Y. Annur, Y. Yelmida, and Z. Zultiniar, "Perengkahan Katalitik Palm Fatty Acid Distillate Menjadi Biofuel Menggunakan katalis Natrium Karbonat dengan variasi Temperatur dan Konsentrasi katalis Natrium Karbonat," J. Online Mhs. Fak. Tek. Univ. Riau, vol. 2, no. 1, pp. $1-6,2015$.

[5] R. Tambun, R. P. Saptawaldi, M. A. Nasution, and O. N. Gusti, "Pembuatan Biofuel dari Palm Stearin dengan Proses Perengkahan Katalitik Menggunakan Katalis ZSM-5," J. Rekayasa Kim. Lingkung., vol. 11, no. 1, p. 46, 2016.

[6] B. Blesvid, Yelmida, and Zultinar, "Perengkahan Katalitik Palm Fatty Acid Distillate ( PFAD ) Menjadi Biofuel Dengan Katalis Abu TKS Variasi Temperatur dan Berat Katalis,” J. Rekayasa Kim. dan Lingkung., vol. vol 10 No, pp. 1-6, 2013.

[7] Y. W. Mirzayanti, F. Kurniawansyah, D. H. Prajitno, and A. Roesyadi, "Zn-Mo/HZSM-5 catalyst for gasoil range hydrocarbon production by catalytic hydrocracking of ceiba pentandra oil," Bull. Chem. React. Eng. Catal., vol. 13, no. 1, pp. 136-143, 2018.

[8] K. Katalitik and M. Sawit, "Konversi Katalitik Minyak Sawit Untuk Menghasilkan Biofuel Menggunakan Silika Alumina Dan Hzsm-5 Sintesis," Reaktor, vol. 13, no. 1, pp. 37-43, 2012.

[9] R. Rasyid, A. Prihartantyo, M. Mahfud, and A. Roesyadi, "Hydrocracking of Calophyllum inophyllum oil with non-sulfide CoMo catalysts," Bull. Chem. React. Eng. Catal., vol. 10, no. 1, pp. 61-69, 2015.

[10] N. Sirajudin, K. Jusoff, S. Yani, L. Ifa, and A. Roesyadi, "Biofuel production from catalytic cracking of palm oil," World Appl. Sci. J., vol. 26, no. 26, pp. 67-71, 2013.

[11] M. A. Hazzamy and I. Zahrina, "Pembuatan Biofuel dari Minyak Goreng Bekas Melalui Proses Catalytic Cracking dengan Katalis Fly Ash,” 2013. 